(c) 2018 - ISSN 1807-2577

\title{
Analysis of the relationship of the vertical extension of mouth opening with muscle rigidity and sociodemographic factors in Parkinson's disease
}

\author{
Análise da relação da extensão vertical da abertura de boca com a rigidez \\ muscular e fatores sociodemográficos na doença de Parkinson \\ Tales Severiano da SILVA ${ }^{a *}$ (D), Jonatas Silva de OLIVEIRA ${ }^{a}$ (D), Patrícia Fernanda FACCIO ${ }^{b}$ (D), \\ Maria das Graças Wanderley de Sales CORIOLANO ${ }^{b} \mathbb{0}$, Carla Cabral dos Santos Accioly LINS ${ }^{b}$ \\ aUFPE - Universidade Federal de Pernambuco, Faculdade de Odontologia, Recife, PE, Brasil \\ bUFPE - Universidade Federal de Pernambuco, Programa de Pós-graduação em Gerontologia, Recife, PE, Brasil
}

How to cite: Silva TS, Oliveira JS, Faccio PF, Coriolano MGWS, Lins CCSA. Analysis of the relationship of the vertical extension of mouth opening with muscle rigidity and sociodemographic factors in Parkinson's disease. Rev Odontol UNESP. 2021;50:e20210035. https://doi.org/10.1590/1807-2577.03521

\section{Resumo}

Introdução: As alterações causadas pela rigidez na Doença de Parkinson (DP) podem afetar a musculatura mandibular, mas há uma escassez de estudos publicados sobre seu impacto na abertura bucal. Objetivo: Analisar a relação da extensão vertical da abertura de boca com a rigidez muscular e os fatores sociodemográficos de idosos com a DP. Material e método: Trata-se de um estudo transversal, quantitativo, que coletou dados de uma pesquisa primária realizada no Hospital das Clínicas da Universidade Federal de Pernambuco, em 2018. Apanhou-se dados dos prontuários e do questionário: Critério de Diagnóstico de Pesquisa para Disfunções Temporomandibulares (RDC/TMD). A amostra foi composta por 81 parkinsonianos e caracterizadas em: variáveis sociodemográficas e presença ou ausência de rigidez muscular. As medidas de extensão vertical de abertura de boca avaliadas foram: abertura de boca sem auxílio e sem dor (ABASD) e abertura máxima da boca sem auxílio (AMBSA). Aplicou-se os testes de correlação linear de Pearson e de correlação de Spearman para averiguar relação entre as variáveis contínuas. Análises de associações foram realizadas através da regressão logística simples. Nível de significância de p<0,05. Resultado: A limitação de abertura de boca não apresentou relação com a idade e o sexo. 0 maior nível de significância foi entre a abertura de boca sem auxílio e sem dor e a rigidez muscular $(p=0,012)$ e a escolaridade $(p=0,038)$. Conclusão: A limitação de abertura de boca nas pessoas com DP se mostrou relacionada a rigidez muscular e a escolaridade mais baixa.

Descritores: Doença de Parkinson; rigidez muscular; mandíbula; músculos da mastigação; fatores socioeconômicos.

\begin{abstract}
Introduction: Changes caused by the rigidity of Parkinson's Disease (PD) can affect the mandibular musculature. However, few studies have been published about its impact on the oral opening. Objective: To analyze the relationship of the vertical extension of the oral opening with muscular rigidity and sociodemographic factors of the elderly with PD. Material and method: This is a cross-sectional, quantitative study that collected data from a primary study conducted at the Hospital das Clínicas of the Federal University of Pernambuco in 2018. Data were collected from medical records and from the questionnaire, Research Diagnostic Criterion for Temporomandibular Disorders (RDC/TMD). The sample was composed of 81 parkinsonians and characterized using: sociodemographic variables and the presence or absence of muscular rigidity. The measures of vertical extension of the oral opening evaluated were: mouth opening without assistance and without pain (ABASD), and maximum mouth opening without assistance (AMBSA). The Pearson's linear correlation and Spearman's correlation tests were applied to investigate the relationship among the continuous variables. Analyses of association were conducted using simple logistic regression. The level of significance was set at $\mathrm{p}<0.05$. Result: Limitation of the oral opening was not related to age or sex. The greatest level of significance was between mouth opening without assistance and without pain
\end{abstract}


and muscular rigidity $(\mathrm{p}=0.012)$, and years of schooling $(\mathrm{p}=0.038)$. Conclusion: The limitation of mouth opening in people with PD was shown to be related to muscular rigidity and fewer years of schooling.

Descriptors: Parkinson's disease; muscular rigidity; mandibular; mastication muscles; socioeconomic factors.

\section{INTRODUCTION}

Parkinson's Disease (PD) ranks second among the most frequent neurodegenerative diseases among the elderly, with a significant increase in its incidence over time ${ }^{1}$. It is characterized by the continuous loss of dopaminergic neurons in the compact part of the substantia nigra of the mesencephalon, resulting in the depletion of dopamine in the nigrostriatal pathway2.

The result of changes in the dopaminergic system that results from PD mainly affects the motor system, generating a series of signs, among which bradykinesia, resting tremor, some postural changes and muscular rigidity like Cardinals ${ }^{3}$, stand out.

Implications in the masticatory and facial muscles, essentially regarding their dynamic mechanisms, indicate that the damage to the dopaminergic system produces progressive muscular rigidity, making it difficult to perform basic functions in those regions ${ }^{4-6}$, consequently compromising the quality of life of these individuals. It is known that changes inherent in PD modify the synergism among the masticatory and facial muscles, causing parafunctionality, in which the mechanisms are still not completely understood ${ }^{7}$.

Hypomimia is a prominent clinical feature in people with Parkinson's, due to a reduction in the action of the muscles of facial expression resulting from high tension and contraction ${ }^{8}$. There is a relationship of this clinical sign with the insufficient movement of the perioral muscles, possibly culminating in the reduction of the oral opening amplitude, compromising functions such as chewing, due to the difficulty in securing the food bolus 9 .

The number of studies relating the biodynamics of the mandibular musculature with the extension of oral opening in persons with Parkinson's is still small. However, they do indicate that the impact of the rigidity affects the range of movement, when compared to individuals without the disease $\mathrm{e}^{10-12}$. In people with Parkinson's who have rigidity as the predominant sign rather than those in whom the tremor predominates, this dysfunction seems to be more significant ${ }^{11}$. Thus, it makes sense that certain stomatognathic functions such as mandibular movement, related to chewing, swallowing and speaking, may be impaired by the presence of rigidity of PD ${ }^{11,13}$.

Considering the high prevalence of PD, the scarcity of studies related to mandibular rigidity in this disease and the importance of chewing and swallowing for the quality and maintenance of life of these individuals, the present study aimed to verify whether a relationship of the vertical extension of the oral opening with the clinical manifestation of muscular rigidity and with sociodemographic factors in elderly persons with Parkinson's Disease exists.

\section{MATERIAL AND METHOD}

This is an observational, cross-sectional, quantitative study that used a secondary study as a data source. The secondary study was conducted at the Hospital das Clínicas of the Federal University of Pernambuco, UFPE, from January to August of 2018 through the "Projeto PróParkinson" ("Pro-Parkinson's Project").

\section{Sample and Data Collection}

Following the collection from the 2018 database, 81 medical records of elderly persons with Parkinson's Disease were included as participants in this study. Their data met the following criteria: 
having a clinical diagnosis of idiopathic PD in stages 1 to 3, established using Hoehn and Yahr's Staging Scale of Disability ${ }^{14}$; being under the influence of an anti-Parkinsonian drug; having natural teeth or using partial/total or fixed dental prostheses; appropriately oriented persons maintaining their independence. The following people were excluded: those presenting other neurological diseases associated with PD; with cognitive impairment; edentulous in both dental arches and/or without prosthetics; with a history of mandible surgery or neurological surgery for Parkinson's Disease.

The dependent variable extracted was the extension of vertical movement. This was obtained by consulting item 4 of axis II of the Research Diagnostic Criterion for Temporomandibular Disorders (RDC/TMD) ${ }^{15}$ questionnaire in the database. The extension of the vertical movement is in millimeters, corresponding to the distance between the incisal edges of the upper and lower incisors, measured with a digital caliper. Two measurements were taken from each patient: mouth opening without assistance and without pain (ABSAD) (interincisal distance with the mandible in a comfortable position and after opening the mouth to the maximum possible without assistance and without feeling any pain) and the maximum opening of the mouth without assistance (AMBSA) (interincisal distance with the mandible in a comfortable position and after opening the mouth the maximum possible even if pain was felt).

Rigidity of the mandible was considered as an independent clinical variable. Rigidity is one of the cardinal signs of PD, considered one of the necessary criteria for the diagnosis of the disease ${ }^{14}$. To obtain information about the presence or absence of mandibular rigidity, we referred to question number 15.e. ("Do you feel your mandible tired or mouth sore when you wake up in the morning?") from the RDC/TMD questionnaire. Responses of "yes" or "no" were recorded as the presence or absence, respectively, of rigidity in the mandibular region.

The sociodemographic factors were collected from the medical records, and are as follows: age, from the date of birth until the date of data collection; sex, male or female; years of schooling, considered to be the number of years of study.

The measurements collected were compared to the standard of normality of minimum and maximum mouth opening proposed by Okeson ${ }^{16}$, which ranges from $40 \mathrm{~mm}$ to $60 \mathrm{~mm}$. Less than $40 \mathrm{~mm}$ is considered a limitation of opening of the mouth.

\section{Data Analysis}

The collected data were tabulated using the Microsoft Excel ${ }^{\mathrm{TM}}$ spreadsheets and afterward expressed through quantitative univariate analysis. The dependent variable of interest was the extension of the vertical movement of mouth opening (ABSAD and AMBSA), and the independent variables were: age (in years), sex (binary variable, male and female), years of schooling (in years of instruction) and mandibular rigidity (binary variable, present or absent).

To verify the normality of the data, the Komolgorov-Smirnov Test was conducted, followed by the Pearson's correlation (extension of vertical movement versus age) and Spearman's correlation (extension of vertical movement versus years of schooling) tests. Simple logistic regression was conducted for the association of binary variables. The statistical program BioEstat v.5.3 ${ }^{\circledR}$ was used, considering $\mathrm{p}<0.05$ as the level of significance in all tests.

\section{Ethical Considerations}

The present study was conducted only after approval by the Ethics Committee for Research with Human Beings at the Federal University of Pernambuco, UFPE (decision no 3.824.455, February, 2020). 


\section{RESULT}

Most of the persons in the sample were male (67\%), with a mean age of $69( \pm 6)$ years and 8 years of schooling. Of the total, $48 \%$ were found with Stage 2 (moderate disability) of Parkinson's Disease and 18 (22\%) were diagnosed with muscular rigidity.

Table 1 shows the mean value of the ABSAD, separated by the sociodemographic data. All values were below the standard of normality (less than $40 \mathrm{~mm}$ ), with the females showing a lower number than the others $(38.1 \mathrm{~mm})$.

Table 1. Minimum, maximum and mean values of mouth opening extension without assistance and without pain according to: age, sex, years of school and muscular rigidity

\begin{tabular}{lccc}
\hline \multicolumn{1}{c}{ Variables } & Minimum value (mm) & Maximum value (mm) & $\begin{array}{c}\text { Mean value in mm } \\
\text { (sd) }\end{array}$ \\
\hline $\begin{array}{l}\text { Age (years) } \\
\text { Sex }\end{array}$ & 21 & 55 & $38.8(7.38)$ \\
Female (n=27) & 24 & & \\
Male (n=54) & 21 & 50 & $38.1(7.8)$ \\
& & 55 & $39.2(7.1)$ \\
Years of school & 21 & 55 & $38.8(7.38)$ \\
& & & \\
Muscular rigidity & & & $39.1(6.5)$ \\
No (n=63) & 25 & 52 & $37.9(9.9)$ \\
Yes (n=18) & 21 & 55 & \\
\hline
\end{tabular}

sd: standard deviation; mm: millimeters.

Tables 1 and 2 show that the lowest and highest measurements of mouth opening were 21 and 62 millimeters, respectively. As Table 2 shows, the mean AMBSA values in relation to mandibular rigidity, and to the sex, age and years of schooling factors, surpassed the value of $40 \mathrm{~mm}$. That is, they fall within the normal pattern.

Table 2. Minimum, maximum and mean values of the maximum extension of the mouth opening without assistance according to: age, sex, years of school and muscular rigidity

\begin{tabular}{lccc}
\hline \multicolumn{4}{c}{ Maximum opening of the mouth without assistance (AMBSA) } \\
\hline \multicolumn{1}{c}{ Variables } & Minimum value (mm) & Maximum value (mm) & Mean value in mm (sd) \\
& 29 & 62 & $44.42(7.4)$ \\
Age (years) & & & $43(8.1)$ \\
Sex & 29 & 55 & $45.1(7)$ \\
Female (n=27) & 30 & 62 & $44.42(7.4)$ \\
Male (n=54) & 29 & 62 & \\
Years of school & & & $44.4(6.7)$ \\
Muscular rigidity & 29 & 58 & $44.3(9.8)$ \\
No (n=63) & 29 & 62 & \\
Yes (n=18) & & & \\
\hline
\end{tabular}

sd: standard deviation; mm: millimeters.

Table 3 shows that years of schooling $(\mathrm{p}=0.038)$ and muscular rigidity $(\mathrm{p}=0.012)$ were factors that had a statistically significant relationship to opening of the mouth without assistance and without pain. Other factors did not influence ABSAD. 
Table 3. Sociodemographic factors and mandibular rigidity related to the extension of the mouth opening without assistance and without pain

\begin{tabular}{|c|c|c|c|c|}
\hline \multicolumn{5}{|c|}{ Opening of the mouth without assistance and without pain (ABSAD) } \\
\hline Variables & $\begin{array}{c}\text { Correlation } \\
\text { coefficient }\end{array}$ & CI $(95 \%)$ & $\mathbf{O R}$ & p-value $\left(X^{2}\right)$ \\
\hline ABSAD vs age* & -0.073 & $-0.2-0.15$ & $\mathrm{n} / \mathrm{a}$ & 0.51 \\
\hline ABSAD vs sex** & $\mathrm{n} / \mathrm{a}$ & $0.96-1.09$ & 1.019 & 0.54 \\
\hline ABSAD vs years of school*** & 0.23 & $\mathrm{n} / \mathrm{a}$ & $\mathrm{n} / \mathrm{a}$ & 0.038 \\
\hline ABSAD vs rigidity** & $\mathrm{n} / \mathrm{a}$ & $1.02-1.21$ & 1.11 & 0.012 \\
\hline
\end{tabular}

*Pearson Correlation; ${ }^{* *}$ Simple logistic regression; ${ }^{* * *}$ Spearman's Correlation; OR: odds ratio. CI: confidence interval; $\mathrm{n} / \mathrm{a}$ : not applicable.

No statistically significant relationships were found for the maximum mouth opening without assistance and the independent variables (Table 4).

Table 4. Sociodemographic factors and mandibular rigidity related to the extension of the maximum opening of the mouth without assistance

\begin{tabular}{|c|c|c|c|c|}
\hline \multirow[b]{2}{*}{ Variables } & \multicolumn{4}{|c|}{ Maximum opening of the mouth without assistance (AMBSA) } \\
\hline & $\begin{array}{c}\text { Correlation } \\
\text { coefficient }\end{array}$ & CI $(95 \%)$ & OR & p-value $\left(\mathrm{X}^{2}\right)$ \\
\hline ABSAD vs age* & -0.098 & $-0.31-0.12$ & $\mathrm{n} / \mathrm{a}$ & 0.380 \\
\hline ABSAD vs sex** & $\mathrm{n} / \mathrm{a}$ & $0.98-1.11$ & 1.04 & 0.226 \\
\hline ABSAD vs years of school*** & 0.173 & $\mathrm{n} / \mathrm{a}$ & $\mathrm{n} / \mathrm{a}$ & 0.121 \\
\hline ABSAD $v s$ rigidity** & $\mathrm{n} / \mathrm{a}$ & $0.93-1.07$ & 0.99 & 0.984 \\
\hline
\end{tabular}

*Pearson Correlation; ${ }^{* *}$ Simple logistic regression; ${ }^{* * *}$ Spearman's Correlation; OR: odds ratio. CI: confidence interval; n/a: not applicable.

\section{DISCUSSION}

Studies on the implications of PD in mandibular movement, the factors which modify the behavior of muscular dynamics in this region and, consequently, the quality of life of the individual with PD are scarce in the literature ${ }^{7,17}$. This obstacle raises the issue of whether other reasons or causes of alterations in this area would be involved.

The present study found no relationship between age, sex and income factors with the vertical extension of the mouth opening. However, some considerations are appropriate. Frequently, an unfavorable economic situation along with similar statistics in relation to the predominance of males (identified in the present study) are found in studies that involve persons with Parkinson's ${ }^{10,18}$; and, there are no studies relating them to facial and oral motricity. Thus, it can be seen that the economic dimension plays an important role in dealing with the disease as a whole, bearing in mind that it is one factor that mobilizes adherence to treatment, which is essential in alleviating signs and symptoms, such as rigidity and tremor ${ }^{19}$.

In relation to age group, a study by Góis ${ }^{20}$ indicated that there is greater probability of developing motor disorders among older persons with PD, including changes in the facial region. The research also shows that older age groups are more likely to develop Parkinson's Disease.

The present study identified that the mouth opening extension without assistance and without pain was associated with muscular rigidity. The finding refers to the study conducted by Albuquerque et al. ${ }^{2}$, carried out through electrognathography, in which they analyzed the speed and amplitude of the masticatory movements of persons in three groups: PD with predominance of rigidity, PD with a predominance of tremor, and individuals without the disease. Unlike the 
others, the PD group with predominance of rigidity stood out by presenting a significant decrease in mouth opening amplitude. The same happened to them in relation to masticatory movements, signaling a greater risk for this group in the performance of oral functions. Another relevant finding also showed that individuals with PD, in general, have a decrease in the speed of bodily movement, including the mandibular muscles.

With progressive muscular rigidity being responsible for this condition, and following the same line of results as the present study, it is a fact that there is aggravation in the mandibular dynamics in persons with PD, with the sequelae of decreased opening of the mouth, as some findings indicate6,10,11. This temporary or permanent disorder in the activity of the stomatognathic system, still little studied, indicates that a drop in dopaminergic production influences the intensity of the rigidity, not disregarding other factors ${ }^{12}$.

For Barros et al. ${ }^{9}$, the rigidity of the facial expression muscles, notably the perioral muscles, exerts an influence on the oral opening. Added to the slowness of the movements (bradykinesia) and the greater difficulty of coordinating oral actions, which are present in persons with Parkinson's, this rigidity becomes an obstacle to activities that demand these muscles, including: eating (chewing, swallowing), laughing, speaking and expressing feelings.

This study found a correlation between years of schooling and ABSD. An intriguing fact, since the negative impact of low schooling on the executive functions, which are linked to the functioning of the pre-frontal cortex, has been pointed out in individuals both with ${ }^{21}$ and without ${ }^{22}$ Parkinson's Disease, although there are no specific studies that indicate repercussions in the stomatognathic system. It should be considered that other sociocultural variables can influence this performance, not only the educational level ${ }^{23}$.

Finally, in a study by Diniz et al. ${ }^{24}$, results were found that explain how a higher level of education is considered a protective factor against the development of neurodegenerative dementia, frequent among the elderly. Furthermore, a higher level of education is associated with lower severity of motor disability ${ }^{25}$. Under this circumstance, health professionals, when evaluating the elderly with PD, should consider this variable carefully.

A limitation of the present study was the moderate number of participants, given that there is still a barrier regarding access of persons with PD to dental appointments and other health professionals.

It is important to seek out other determining factors for mouth opening and how they modify the mandibular and oral dynamics. For this, future studies with a longitudinal aspect should be designed, enriching the discussion to determine other hypotheses for cause and effect among elderly persons with PD and mouth opening limitations. On the other hand, the present study encourages the investigation of the role of education, a protective factor for various neurodegenerative disorders, about the motor conditions of persons with PD, given the scarcity of studies.

The results obtained in the present study can be considered of clinical relevance, especially for Dentistry and Phonoaudiology. It focuses on professionals with knowledge of the correct therapy to reduce consequent oral disorders, which impact upon the masticatory, swallowing and even speaking activities, that result in a reduction of the quality of life of Parkinsonians. Therefore, the results and reflections presented here serve as a guide for health professionals, beyond technical-mechanical care. It is necessary to know which factors, beyond the disease, are significant for dealing with it.

\section{CONCLUSION}

The mouth opening extension in persons with Parkinson's Disease is related to the clinical characteristics of the disease and to sociodemographic factors. Among these, muscular rigidity and the lower level of education appear more relevant for the mouth opening limitation. 


\section{REFERENCES}

1. Cabreira V, Massano J. Parkinson's disease: clinical review and update. Acta Med Port. 2019 Oct;32(10):661-70. http://dx.doi.org/10.20344/amp.11978. PMid:31625879.

2. Carrete H Jr. Parkinson's disease and atypical parkinsonism: the importance of magnetic resonance imaging as a potential biomarker. Radiol Bras. 2017 Jul-Aug;50(4):5-6. http://dx.doi.org/10.1590/0100-3984.2017.50.4e1.

3. Silva ABG, Pestana BC, Hirahata FAA, Horta FBS, Oliveira ESBE. Doença de Parkinson: revisão de literatura. Brazilian Journal of Development. 2021 Maio;7(5):47677-98. https://doi.org/10.34117/bjdv7n5-258.

4. Heckmann SM, Heckmann JG, Weber HP. Clinical outcomes of three Parkinson's disease patients treated with mandibular implant overdentures. Clin Oral Implants Res. 2000 Dec;11(6):566-71. http://dx.doi.org/10.1034/j.1600-0501.2000.011006566.x.

5. Sarr MM, Pinto S, Jankowski L, Teston B, Purson A, Ghio A, et al. Contribution de la mesure de la pression intra-orale pour la compréhension des troubles de la coordination pneumophonique dans la dysarthrie parkinsonienne. Rev Neurol. 2009 Dec;165(12):1055-61. http://dx.doi.org/10.1016/j.neurol.2009.03.012. PMid:19406446.

6. Bakke M, Larsen SL, Lautrup C, Karlsborg M. Orofacial function and oral health in patients with Parkinson's disease. Eur J Oral Sci. 2011 Feb;119(1):27-32. http://dx.doi.org/10.1111/j.16000722.2010.00802.x. PMid:21244508.

7. Karlsson S, Persson M, Johnels B. Levodopa induced ON-OFF motor fluctuations in Parkinson's disease related to rhythmical masticatory jaw movements. J Neurol Neurosurg Psychiatry. 1992 Apr;55(4):304-7. http://dx.doi.org/10.1136/jnnp.55.4.304. PMid:1316430.

8. Galhardo MMAMC, Amaral AKFJ, Vieira ACC. Characterizing cognitive disorders in Parkinson's disease. Rev CEFAC. 2009;11(Suppl. 2):251-7. http://dx.doi.org/10.1590/S1516-18462009000600015.

9. Barros ALS, Silveira EGC, Souza RCM, Freitas LC. Uma análise do comprometimento da fala em portadores de doença de Parkinson. Revista Neurociências. 2019;12(3):123-9. http://dx.doi.org/10.34024/rnc.2004.v12.8858.

10. Robertson LT, St George RJ, Carlson-Kuhta P, Hogarth P, Burchiel KJ, Horak FB. Site of deep brain stimulation and jaw velocity in Parkinson disease. J Neurosurg. 2011 Nov;115(5):985-94. http://dx.doi.org/10.3171/2011.7.JNS102173. PMid:21838506.

11. Albuquerque LCA, Silva HJ. Jaw movement in people with Parkinson's disease. CoDAS. 2016 Abr;28(2):193-6. http://dx.doi.org/10.1590/2317-1782/20162015057. PMid:27191885.

12. Albuquerque LCA, Silva HJ, Pernambuco LA, Lima SJH, Cunha DA. Amplitude and speed of masticatory movements in patients with Parkinson's disease. Rev CEFAC. 2017 Fev;19(1):1-6.

13. Almeida MAF, Hubner LS, Dornelles S. Avaliação do efeito imediato de exercício de trato vocal semiocluído no mecanismo velofaríngeo em cinco portadores de fissura labiopalatina: estudo piloto. Clin Biomed Res. 2018;38(1):58-65. http://dx.doi.org/10.4322/2357-9730.75973.

14. Hoehn MM, Yahr MD. Parkinsonism: onset, progression, and mortality. Neurology. 1967 May;17(5):427-42. http://dx.doi.org/10.1212/WNL.17.5.427. PMid:6067254.

15. Lucena LBS, Kosminsky M, Costa LJ, Góes PSA. Validation of the portuguese version of the RDC/TMD Axis II questionnaire. Braz Oral Res. 2006 Oct-Dec;20(4):312-7. http://dx.doi.org/10.1590/S180683242006000400006. PMid:17242791.

16. Okeson JP. Tratamento das desordens temporomandibulares. Rio de Janeiro: Elsevier; 2013.

17. Robertson LT, Horak FB, Anderson VC, Burchiel KJ, Hammerstad JP. Assessments of axial motor control during deep brain stimulation in parkinsonian patients. Neurosurgery. 2001 Mar;48(3):544-51. http://dx.doi.org/10.1097/00006123-200103000-00017. PMid:11270544. 
18. Faccio PF, Tavares RB, Asano NMJ, Asano AGC, Coriolano MGWS, Lins CCSA. Dor crônica e depressão como fatores associados à disfunção temporomandibular em pessoas idosas com doença de Parkinson. Rev CEFAC. 2020;22(4):e7719. http://dx.doi.org/10.1590/1982-0216/20202247719.

19. Marchi KC, Chagas MHN, Tumas V, Miasso AI, Crippa JAS, Tirapelli CR. Adesão à medicação em pacientes com doença de Parkinson atendidos em ambulatório especializado. Cien Saude Colet. 2013 Mar;18(3):855-62. http://dx.doi.org/10.1590/S1413-81232013000300031. PMid:23546212.

20. Góis ALB. A incidência da doença de Parkinson em idosos na assistência de condutas e comportamentos motores em domicílios do Rio de Janeiro. Fisioterapia Brasil. 2018 Mar;7(3):177-80. http://dx.doi.org/10.33233/fb.v7i3.1897.

21. Parente MAMP, Scherer LC, Zimmermann N, Fonseca RP. Evidências do papel da escolaridade na organização cerebral. Neuropsicol Latinoam [Internet]. 2009 Jan [cited 2021 July 7];1(1):72-80. Available from: http://pepsic.bvsalud.org/scielo.php?script=sci_abstract\&pid=S207594792009000100009\&lng=pt\&nrm=i

22. Macuglia GR, Rieder CRM, Trentini LB, Filho NH, Moraes AL, Almeida RMM. Comprometimento executivo nas fases leve à grave da doença de Parkinson. PSICO. 2015;46(2):198-207. http://dx.doi.org/10.15448/1980-8623.2015.2.15236.

23. Stern Y. Cognitive reserve. Neuropsychologia. 2009 Aug;47(10):2015-28. http://dx.doi.org/10.1016/j.neuropsychologia.2009.03.004. PMid:19467352.

24. Diniz BSO, Volpe FM, Tavares AR. Nível educacional e idade no desempenho no Miniexame do Estado Mental em idosos residentes na comunidade. Arch Clin Psychiatry. 2007;34(1):13-7. http://dx.doi.org/10.1590/S0101-60832007000100002.

25. Sousa NMF, Macedo RC. Relationship between cognitive performance and mobility in patients with Parkinson's disease: a cross-sectional study. Dement Neuropsychol. 2019 Oct-Dec;13(4):403-9. http://dx.doi.org/10.1590/1980-57642018dn13-040006. PMid:31844493.

\section{CONFLICTS OF INTERESTS}

The authors declare no conflicts of interest.

\section{${ }^{*}$ CORRESPONDING AUTHOR}

Tales Severiano da Silva, UFPE - Universidade Federal de Pernambuco, Faculdade de Odontologia, Av. Prof. Moraes Rego, 1235, Cidade Universitária, 50670-90 Recife - PE, Brasil, email: talesseveriano@gmail.com

Received: July 7, 2021

Accepted: September 16, 2021 